\title{
Particularities and Clinical Applicability of Saccharin Transit Time Test
}

\author{
Fernanda Rodrigues ${ }^{1}$ Ana Paula Freire ${ }^{10}$ Juliana Uzeloto ${ }^{1}$ Rafaella Xavier ${ }^{1}$ Juliana Ito ${ }^{1}$ \\ Marceli Rocha ${ }^{1}$ Renata Calciolari ${ }^{1}$ Dionei Ramos ${ }^{1}$ Ercy Ramos ${ }^{1}$ \\ 1 Department of Physiotherapy, Universidade Estadual Paulista Júlio \\ de Mesquita Filho, Campus de Presidente Prudente, Presidente \\ Prudente, SP, Brazil \\ Int Arch Otorhinolaryngol 2019;23:229-240. \\ Address for correspondence Ana Paula Freire, PhD, Departamento de \\ Fisioterapia, Universidade Estadual Paulista Júlio de Mesquita Filho, \\ Campus de Presidente Prudente, Rua Roberto Simonsen, 305, \\ Presidente Prudente, SP, 19060-900, Brazil \\ (e-mail: anapcff@hotmail.com).
}

\begin{abstract}
Keywords

- mucociliary clearance

- airway management

- mucus

Introduction The importance of mucociliary clearance (MCC) for the respiratory system homeostasis is clear. Therefore, evaluating this defense mechanism is fundamental in scientific research and in the clinical practice of pulmonology and of associated areas. However, MCC evaluation has not been so usual due to the complexity of methods that use radiolabeled particles. Nevertheless, as an interesting alternative, there is the saccharin transit time (STT) test. This method is reproducible, simple to perform, noninvasive, does not demand high costs, and has been widely used in studies of nasal MCC. Although the STT test is widely used, there is still lack of a detailed description of its realization.

Objective The present literature review aims to provide basic information related to the STT test and to present the findings of the previous studies that used this method, discussing variations in its execution, possible influences on the obtained results and limitations of the method, as well as to relate our experience with the use of STT in researches.

Data Synthesis There are several factors that can alter the results obtained from STT tests, which would raise difficulties with proper interpretation and with the discussion of the results among different studies.

Conclusions Saccharin transit time is a widely used method for the evaluation of nasal MCC, and therefore, the standardization related to the previous and concurrent to test orientations, and also its execution, become essential to improve its accuracy, and allow comparisons among different studies.
\end{abstract}

\section{Introduction}

Mucociliary clearance (MCC) is an important respiratory system defense mechanism, since the human airway surfaces are constantly exposed to various particles and microorganisms present in the ambient air. ${ }^{1-4}$ Its effectiveness depends on the quantity and on the quality of the mucus, on the structure, the synchrony and frequency of ciliary beating, and on the interaction between these components. ${ }^{5-7}$

(D) Ana Paula Freire's ORCID is https://orcid.org/0000-0002-28055746.

received

January 23, 2018

accepted

October 6, 2018

published online

February 15, 2019 10.1055/s-0038-1676116. ISSN 1809-9777.
Mucus is a barrier that entraps inhaled microorganisms in its mobile layer, and the cilia are the propellants, which act through coordinated beating. The interaction of these components is responsible for the removal of microorganisms from the upper and lower airways toward the oropharynx, where they are swallowed or expectorated, which avoids them from entering into direct contact with epithelial cells or reaching the alveoli. ${ }^{8-12}$

Since MCC is fundamental in lung defense, several methods have been described to evaluate it: some analyze separately the mechanical condition of the cilia (video microscopy, photometric method) $)^{3,13}$ or of the mucus (contact angle measurements, displacement of mucus by simulated cough
Copyright @ 2019 by Thieme Revinter Publicações Ltda, Rio de Janeiro, Brazil

\section{License terms}

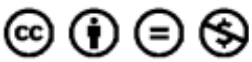


and frog palate), ${ }^{14-16}$ and others evaluate the interaction between the mucus and the cilia (clearance of inhaled radiolabeled particles, saccharin transit time [STT] test). ${ }^{17,18}$

Methods involving radiolabeled particles are used as the reference option to measure MCC. ${ }^{19}$ However, the feasibility of this methodology is limited due to equipment and cost requirements, besides presenting some risks inherent to the exposure to radiation. The STT test was compared with the radioactively tagged particles method in the study of Puchelle et al. ${ }^{19}$ The authors found a good correlation between the methods for absolute results obtained in one measurement day and for changes between two measurement days. The STT is a useful method for scientific research, widely used in nasal MCC studies, as it is a reproducible, ${ }^{18,20,21}$ simple to perform, and noninvasive technique, besides being low-cost, making it an interesting alternative to other methods that require relatively complex, invasive, and expensive equipment, and demand greater technical aptitude from the examiners. ${ }^{12,22-26}$

Given the importance of MCC in lung defense, its evaluation is necessary as a contribution to the clinical and functional screening of the individual. Thus, as the STT test is a practical and effective evaluation method, the present literature review aims to provide basic information related to the STT test and to present the findings of previous studies that used this method, discussing variations in its execution, possible influences on the obtained results, and limitations of the method, besides relating our experience with the use of STT tests in research.

\section{Review of a Particular Subject}

\section{The Method}

The STT test was first described in 1974 by Andersen et al. ${ }^{26}$ It consisted of the insertion of a sodium saccharin particle on the upper surface of the inferior nasal turbinate of the subject.
Next, the subjects were asked to swallow once every minute and to notify the examiner when they noticed a sweet taste. The distance from the start of the mucociliary membrane to the far wall of the pharynx was measured with a probe, and from this measurement the mean velocity was determined.

This method was modified by Rutland et al, ${ }^{27}$ who, prior to the evaluation, kept the subjects for at least an hour in an environmental temperature between 21 and $24^{\circ} \mathrm{C}$, with relative humidity between 30 and $50 \%$, and requested that the subjects blow their nose gently to remove any excess secretion. The saccharin particle was $0.5 \mathrm{~mm}$ in diameter and was placed in the inferior turbinate of one nasal cavity at least $7 \mathrm{~mm}$ behind the anterior end of the turbinate to avoid the area of mucosa where the cilia beat in an anterior direction. Another difference in this study lies in the fact that the subjects were not instructed to swallow regularly and that the distance between the particle placement and the nasopharynx was not measured. Therefore, only the time was obtained, but not the velocity of clearance.

Since then, the STT technique has been used in several studies involving MCC, ${ }^{12,22,24,25,28}$ either to characterize different populations ${ }^{11,21,22,29,30}$ or to evaluate the effect of interventions such as the use of anesthetics, ${ }^{31,32}$ continuous positive airway pressure (CPAP), ${ }^{5,33}$ and smoking cessation. ${ }^{34}$

However, differences are found in the execution of the technique among the published studies, related to the position of the subject, to the manner of introduction of the saccharin particle, to its size, and guidance to the subject being examined ( $\boldsymbol{-}$ Table $\mathbf{1})$.

The pretest guidance found in the literature includes not ingesting alcoholic or caffeine-based substances, such as coffee, tea, soda, and energy drinks; drugs such as anesthetics, analgesics, barbiturates, tranquilizers, and antidepressants; not smoking for at least 12 hours; and not performing vigorous physical activities during the 12 hours preceding the test. ${ }^{22,34-54}$

Table 1 Methodological variations in saccharin transit time test in the literature

\begin{tabular}{|c|c|}
\hline \multicolumn{2}{|l|}{ Variations in STT execution } \\
\hline Positioning of the volunteer & $\begin{array}{l}\text { Seated, with the neck extended, }{ }^{28,35} \text { flexed, }{ }^{29,36} \text { or maintained in the horizontal plane }{ }^{5,12,37} \\
\text { Supine position }\end{array}$ \\
\hline Nostril choice & $\begin{array}{l}\text { Non-obstructed nostril } 2,21,39 \\
\text { Standardization of a specific side }\end{array}$ \\
\hline $\begin{array}{l}\text { Instrument for the } \\
\text { placement of saccharin }\end{array}$ & $\begin{array}{l}\text { Plastic straw } 28 \\
\text { Cotton } 40-42 \\
\text { Surgical pincers }\end{array}$ \\
\hline $\begin{array}{l}\text { Location of } \\
\text { saccharin placement }\end{array}$ & $\begin{array}{l}\text { Inferior nasal turbinate }{ }^{11,30,32} \\
1 \mathrm{~cm} \text { behind the inferior nasal turbinate } \\
\text { Below the middle nasal turbinate }{ }^{12} \\
2 \mathrm{~cm} \text { inside the nostril } 2,28,34,39\end{array}$ \\
\hline Utilized amount of saccharin & $\begin{array}{l}1 \text { particle of } 0.5 \mathrm{~mm},{ }^{12} 1 \mathrm{~mm}^{25,30,32,44,45} \text { or } 1.5 \mathrm{~mm}^{24} \text { in diameter } \\
5 \mathrm{mg},{ }^{2,46} 25 \mathrm{mg},{ }^{22} \text { or } 250 \text { micrograms }(\mu \mathrm{g})^{34}\end{array}$ \\
\hline Guidance during the test & $\begin{array}{l}\text { Not to cough, sneeze, blow, or scratch the nose } e^{2,43,47-50} \\
\text { Breathe normally } 22,51 \text { or through the mouth } 2,39 \\
\text { Swallow normally, }{ }^{12,21,22} \text { every } 30 \text { seconds, }{ }^{40,52,53} \text { every } 60 \text { seconds, }{ }^{5,26} \text { or regularly }\end{array}$ \\
\hline
\end{tabular}

Abbreviations: STT, saccharine transit time. 
This guidance is given due to the fact that MCC changes in different conditions, such as age, level of physical activity in daily life, smoking, and use of drugs and other substances, such as caffeine and alcohol. Therefore, it is essential to consider these aspects and control them, when possible, before evaluating this lung defense mechanism.

The normality values for STT have been published for the Spanish population. Plaza Valía et $\mathrm{al}^{21}$ found a median of 16 minutes, and $50 \%$ of their results ranged from 12 to 20 minutes (interquartile interval). While these values can shed light on what can be expected as a result of this test, they might not be representative of other populations, with different ethnicities and living in different environmental conditions. To the best of our knowledge, there are no studies presenting reference values for other populations.

\section{Factors that Influence MCC}

\section{Age}

The respiratory system undergoes changes with advancing age, such as loss of lung elasticity, decrease in diaphragm strength, lung function decline, and an increase in the susceptibility to infections. ${ }^{22}$ Studies indicate that age also interferes with MCC. ${ }^{11,22}$ A correlation analysis has shown that MCC becomes progressively slower with advancing age, beginning at the early twenties, ${ }^{21,55}$ probably due to an increasing incidence of defects in the structure of the cilia. ${ }^{11}$

\section{Septal Deviations}

Kamani et $\mathrm{al}^{56}$ have shown that young adults with septal deviations presented impaired MCC in both nostrils when compared with matched controls. When looking only at the study group, the concave (opposite side) presented even more impaired MCC than the convex side of the deviation. Therefore, this anatomical alteration might be considered an exclusion criterion for cross-sectional studies comparing different cohorts. In the case of longitudinal/interventional studies, it should be considered, a priori, whether this alteration could implicate possible bias in the findings.

\section{Smoking}

Smoking is an accelerator of lung function decline. ${ }^{57}$ Besides interfering in the respiratory tract, it causes inflammation and mutagenic effects, which can result in the development of malignant neoplasias. ${ }^{58-60}$ Stanley et $\mathrm{al}^{29}$ evaluated the MCC of 29 smokers and of 27 nonsmokers and observed higher values of STT in the first group (20.8 \pm 9.3 minutes) compared with the second $(11.1 \pm 3.8$ minutes $)$. More recently, Proença et $\mathrm{al}^{23}$ also observed a higher STT in smokers after 8 hours of abstinence ( $16 \pm 6$ minutes) compared with nonsmokers ( $10 \pm 4$ minutes). However, immediately after smoking, smokers presented a similar STT to nonsmokers ( $11 \pm 6$ minutes). Most likely, this represents an immediate defense response. Cigarette smoke leads to an increase in the ciliary beat frequency, probably as a consequence of the stimulation of sensory receptors from the epithelium or by the action of inflammatory mediators. Therefore, in addition to the chronic condition of smoking, the influence exerted by acute exposure to cigarette smoke should also be considered before evaluating MCC.

\section{Physical Activity in Daily Life}

Exercise is, in general, classified as a stressful stimulus, ${ }^{61}$ which can generate acute responses and chronic adaptations. ${ }^{62}$ The first is associated with increased levels of adrenergic mediators, ${ }^{63}$ and these stimulate ciliary beat frequency and, therefore, the MCC. ${ }^{64}$ Proença et $\mathrm{al}^{28}$ evaluated the interference of physical activity in daily life in MCC and found that both nonsmokers and even light smokers with a high level of physical activity in daily life presented faster STTs than individuals with a less active or inactive lifestyle.

\section{Ingested Substances}

Some ingested substances also influence the functioning of MCC. It is known that a brief exposure to alcohol can quickly stimulate the cilia, through the production of nitric oxide and the activation of the kinase dependent protein, whereas prolonged exposure blocks the $\beta$-agonist stimulation of kinase protein activity and ciliary beating. 6,65

Caffeine consumption is related to autonomic modulation alteration resulting in an increased respiratory rate and bronchodilatation. ${ }^{66,67}$ It is known that MCC is also, at least in part, influenced by the autonomic system. ${ }^{54}$ It has been shown in humans that anticholinergic agents slow clearance, $^{68}$ while cholinergic stimulation ${ }^{69}$ and sympathomimetic agents speed clearance through changes in the ciliary beat frequency. ${ }^{68,70}$

\section{Drugs}

Some drugs are employed for the purpose of changing MCC. Begrow et $\mathrm{al}^{71}$ observed that the use of standard Myrtol improved MCC in rats. Boek et al $^{72}$ found that MCC improved under the action of salbutamol, while it reduced under sodium chloride, and xylometazoline caused no significant change. Bercin et $\mathrm{al}^{52}$ found that the topical nasal medications xylometazoline hydrochloride, fluticasone propionate, and seawater, which are often used without medical prescription, may worsen the MCC of individuals with nasal air flow lower than $500 \mathrm{ml}$ and concluded that these drugs should be used carefully and selectively in patients with nasal complaints.

Other medications, which are not employed to act on MCC, can also cause alterations as a side effect. Houtmeyers et $\mathrm{al}^{73}$ conducted a review on the effects of routine clinical use of medications on MCC and concluded that anticholinergics (tertiary ammonium compounds), aspirin, anesthetics, and benzodiazepines (tranquilizers and anxiolytics) depress the MCC, probably by decreasing the ciliary beat frequency and mucus secretion. On the other hand, cholinergic agents, methylxanthines (theophylline, aminophylline, and bamifylline), sodium cromoglycate (anti asthmatic), antibiotics (those orally administered for chronic rhinosinusitis, such as penicillin, cephalosporin and sulfonamide), surfactant, hypertonic saline solution, and water aerosol improve the MCC, apparently by increasing the ciliary beat frequency and mucus secretion, and stimulating fluid secretion in the airway surface. 


\section{Circadian Cycle}

The circadian cycle refers to rhythmic biological phenomena that occur in all forms of life and are influenced by the solar cycle (dark/light cycle) and by the environment. In humans, it is related to internal regulators of the central nervous system and interferes with the organization and sequencing of metabolic and physiological events, such as body temperature, blood hormone levels, urinary volume, cognitive and motor performance, sleep-wake cycle, and the breathing control system. ${ }^{74-77}$ The upper and lower airways undergo normal cyclic changes; the size of the tracheobronchial tree decreases at night and increases during the day, and the venous erectile tissue of the nasal mucosa demonstrates normal cycles of congestion and constriction that cause alternations in the air flow from one nostril to the other over a period of several hours.

\section{Environmental Conditions}

Temperature, relative humidity, and altitude also interfere with MCC, as the nose, besides filtering the inhaled air, also participates in heating and humidification processes, ceding heat and water from its mucosa. ${ }^{78,79}$

Experimental and clinical studies have shown decreased MCC under environmental temperature changes ${ }^{80,81}$ due to increased mucus secretion by the nasal epithelium in order to facilitate heat exchange, ${ }^{79}$ and altered ciliary beat frequency, which is slower at lower temperatures. ${ }^{82,83}$

Prolonged exposure to low humidity also results in greater dehydration of the nasal mucosa, which causes a change in the rheological properties of the mucus and impairs ciliary movements. ${ }^{39,84}$

At high altitudes, both conditions, low humidity and temperature, are added together, submitting the respiratory system to a more hostile condition, in which MCC is also impaired. ${ }^{84}$

\section{Studies of the Last Decade}

- Table 2 presents the studies published over the past 10 years in journals indexed in the PubMed and BIREME databases, written in English and Portuguese, found through the keywords mucociliary clearance and saccharin.

\section{Experience Report}

Considering the aspects that interfere in MCC mentioned in the literature, along with the experience acquired after years of use of STT in developed researches, our research group has standardized STT execution as follows:

Previous orientations: Request the patients to abstain from alcoholic substances, foods and beverages containing caffeine, cigarettes, and drugs for at least 12 hours prior to the evaluation and ask them not to perform strenuous physical activity the day before, as these are associated with increased levels of adrenergic mediators that stimulate the ciliary beat frequency, and thus the clearance. ${ }^{6,54,63-67}$ If it is necessary to temporarily cease using any medication to perform the STT, the doctor should be consulted.

Evaluation scheduling: Ensure the subjects present clinic stability. If they are apparently healthy, consider a week free from fever, cough, and/or increased mucous production, since these are common symptoms of respiratory tract infections and it is known that this impairs MCC. ${ }^{85}$ For patients with lung disease, consider 30 days free from exacerbation.

It is essential that the same period of the day is chosen for the evaluations. It is preferable to schedule them in the morning, since the previous night, in most cases, the subjects sleep, and in these sleeping hours they do not make use of the substances previously described, making it easier to complete the required 12 hours of abstinence. In addition, in the first hours of the morning, subjects are normally exposed to environmental pollution for less time until the time of evaluation.

Preparation of the evaluation environment: The environment should be quiet, free from people flow and previously prepared to a maintained temperature of $25^{\circ} \mathrm{C}$ and to a relative humidity between 50 and $60 \%$, since variations in these parameters interfere in the MCC. ${ }^{80}$

Required materials: For the preparation of the environment, an air conditioner unit and a humidifier are needed to ensure the required temperature and relative humidity.

For the placement of sodium saccharin, a plastic straw, trimmed to facilitate the deposition of particles inside the nostril, (-Fig. 1A) should be used.

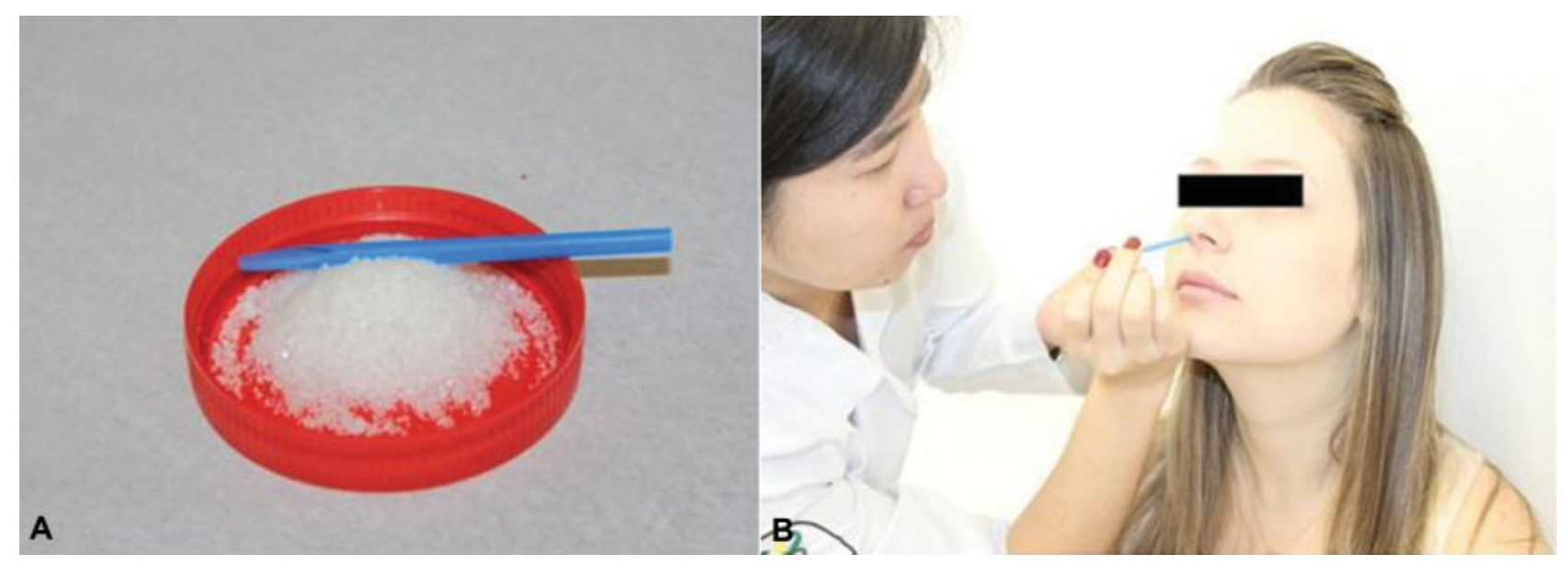

Fig. 1 Saccharin transit time test materials and execution. 
Table 2 Studies published in the last decade that employed the saccharin transit time test to evaluate mucociliary clearance

\begin{tabular}{|c|c|c|c|}
\hline Category & $\begin{array}{l}\text { Author; publication year; } \\
\text { journal and its impact factor }\end{array}$ & Sample & Obtained results \\
\hline $\begin{array}{l}\text { Reference } \\
\text { values }\end{array}$ & $\begin{array}{l}\text { Plaza Valía et } \mathrm{al}^{21} ; 2008 \\
\text { Arch Bronconeumol: } 1.372\end{array}$ & 249 healthy nonsmokers. & $\begin{array}{l}\text { The STT mean was } 17.17 \pm 8.43 \text { minutes, } \\
\text { and the median was } 16(12-20) \text { minutes. } \\
\text { There was no difference between the STTs } \\
\text { of men and women, but they were } \\
\text { positively correlated with age. }\end{array}$ \\
\hline \multirow[t]{4}{*}{$\begin{array}{l}\text { Special } \\
\text { physical } \\
\text { conditions }\end{array}$} & $\begin{array}{l}\text { Deniz et al }\left.\right|^{86} ; 2014 \\
\text { Am J Rhinol Allergy: } 2.302\end{array}$ & $\begin{array}{l}122 \text { patients with mild, moderate and } \\
\text { severe obstructive sleep apnea syndrome } \\
\text { (OSAS), and } 49 \text { healthy subjects as control } \\
\text { group }\end{array}$ & $\begin{array}{l}\text { Mild and moderate OSAS had SST similar to } \\
\text { that of the control group. Severe OSAS had a } \\
\text { slower STT. In all groups, smokers had a } \\
\text { slower STT than nonsmokers. }\end{array}$ \\
\hline & $\begin{array}{l}\text { Baby et } a^{87} ; 2014 \\
\text { Lung India }\end{array}$ & $\begin{array}{l}30 \text { adult smokers and } 30 \text { adult nonsmokers. } \\
\text { Volunteers were healthy and aged between } \\
21 \text { and } 40 \text { years old. }\end{array}$ & $\begin{array}{l}\text { STT was prolonged in smokers in compar- } \\
\text { ison to nonsmokers. STT was also increased } \\
\text { in subjects smokers for a longer time. }\end{array}$ \\
\hline & $\begin{array}{l}\text { Janic et al }{ }^{88} ; 2013 \\
\text { Oral Surg Oral Med Oral } \\
\text { Pathol Oral Radiol: } 1.457\end{array}$ & $\begin{array}{l}144 \text { patients who sustained zygomatico- } \\
\text { maxillary-orbitalis fracture }\end{array}$ & $\begin{array}{l}\text { STT was impaired on the affected side } \\
\text { compared with the control side. However, it } \\
\text { did not vary regardless of age, gender, } \\
\text { degree of injury, method of treatment, time } \\
\text { since fracture, and duration of surgery }\end{array}$ \\
\hline & $\begin{array}{l}\text { Xavier et al }{ }^{49} ; 2013 \\
\text { Respiration: } 2.615\end{array}$ & $\begin{array}{l}24 \text { adult nonsmokers and } 75 \text { smokers, } \\
\text { divided into mild }(n=15), \text { moderate } \\
(n=34) \text {, and heavy }(n=27) \text { smokers. }\end{array}$ & $\begin{array}{l}\text { Heavy and moderate smokers had a greater } \\
\text { STT than mild and nonsmokers. } \\
\text { STT correlated with the concentration of } \\
\text { exCO and cigarettes/day. }\end{array}$ \\
\hline \multirow{8}{*}{$\begin{array}{l}\text { Special } \\
\text { physical } \\
\text { conditions }\end{array}$} & $\begin{array}{l}\text { Altuntas et al }{ }^{50} ; 2013 \\
\text { J Craniofac Surg: } 0.686\end{array}$ & $\begin{array}{l}20 \text { children infected with Crimean Congo } \\
\text { hemorrhagic fever and } 20 \text { healthy children. }\end{array}$ & $\begin{array}{l}\text { There was no difference between the STTS } \\
\text { of infected and healthy children. }\end{array}$ \\
\hline & $\begin{array}{l}\text { Proença et } \mathrm{al}^{23} ; 2011 \\
\text { Rev Port Pneumol: } 0.562\end{array}$ & $\begin{array}{l}19 \text { active smokers and } 19 \text { nonsmokers } \\
\text { (control). }\end{array}$ & $\begin{array}{l}\text { Immediately after smoking, the STT of the } \\
\text { smokers was similar to that of the control } \\
\text { group. } \\
\text { After } 8 \text { hours of smoking abstinence, the } \\
\text { STT of the smokers was slower than that of } \\
\text { the control group. }\end{array}$ \\
\hline & $\begin{array}{l}\text { Naiboglu et al }{ }^{25} ; 2010 \\
\text { J Laryngol Otol: } 0.681\end{array}$ & $\begin{array}{l}18 \text { adult patients with unilateral or bilateral } \\
\text { epiphora and } 20 \text { healthy adults. }\end{array}$ & $\begin{array}{l}\text { The STT of the patients was higher than that } \\
\text { of healthy individuals. } \\
\text { The STT was also higher in the affected } \\
\text { nostril compared with the contralateral. }\end{array}$ \\
\hline & $\begin{array}{l}\text { Kirtsreesakul et } \mathrm{al}^{89} ; 2009 \\
\text { Laryngoscope: } 1.979\end{array}$ & $\begin{array}{l}73 \text { patients with mild intermittent allergic } \\
\text { rhinitis (MIAR), moderate-severe intermit- } \\
\text { tent allergic rhinitis (MSIAR), mild persistent } \\
\text { allergic rhinitis (MPAR), or moderate-severe } \\
\text { persistent allergic rhinitis (MSPAR). }\end{array}$ & $\begin{array}{l}\text { MSPAR had the worst STT, followed by the } \\
\text { MSIAR, MPAR, and MIAR groups. } \\
\text { The STT correlated with the symptoms. }\end{array}$ \\
\hline & $\begin{array}{l}\text { Delehaye et al }{ }^{37} ; 2009 \\
\text { Auris, Nasus, Larynx: } 0.948\end{array}$ & 50 gastroesophageal reflux patients. & $\begin{array}{l}74 \% \text { of the patients, who had only typical } \\
\text { gastroesophageal symptoms, had a higher } \\
\text { STT than the other individuals, who also } \\
\text { reported extraesophageal symptoms. }\end{array}$ \\
\hline & $\begin{array}{l}\text { Yoruk et al }{ }^{53} ; 2008 \\
\text { Rhinology: } 1.72\end{array}$ & $\begin{array}{l}83 \text { young men with silicosis and } 84 \\
\text { apparently healthy individuals (control). }\end{array}$ & $\begin{array}{l}\text { The STT of the patients was higher than that } \\
\text { of the control subjects. }\end{array}$ \\
\hline & $\begin{array}{l}\text { Boatsman et al }{ }^{48} ; 2006 \\
\text { Otolaryngol Head } \\
\text { Neck Surg: } 1.625\end{array}$ & $\begin{array}{l}83 \text { young men with silicosis and } 84 \\
\text { apparently healthy individuals (control). }\end{array}$ & $\begin{array}{l}\text { The STT of the patients was higher than that } \\
\text { of the control subjects. }\end{array}$ \\
\hline & $\begin{array}{l}\text { Kamani et al }\left.\right|^{56} ; 2006 \\
\text { Laryngoscope: } 1.979\end{array}$ & $\begin{array}{l}20 \text { patients with nasal septal deviation and } \\
30 \text { patients without septal deviation } \\
\text { (control). }\end{array}$ & $\begin{array}{l}\text { In patients with septal deviation, the STT } \\
\text { was higher in the opposite nostril to the } \\
\text { deviation, and both nostrils of these } \\
\text { patients resulted in a higher STT than that of } \\
\text { the control group. }\end{array}$ \\
\hline \multirow[t]{2}{*}{$\begin{array}{l}\text { Special } \\
\text { physical } \\
\text { conditions }\end{array}$} & $\begin{array}{l}\text { Nakagawa et al }{ }^{2} ; 2005 \\
\text { Chest: } 5.85\end{array}$ & $\begin{array}{l}16 \text { ICU patients who did not receive } \\
\text { mechanical ventilation and had no } \\
\text { nasogastric or enteral intubation, and } \\
16 \text { healthy individuals (control). }\end{array}$ & $\begin{array}{l}\text { The STT improved in the recovery period } \\
\text { after discharge from the ICU compared with } \\
\text { at the time of admission. } \\
\text { In healthy subjects, the STT was not } \\
\text { changed. }\end{array}$ \\
\hline & $\begin{array}{l}\text { Rosen et al }{ }^{43} ; 2005 \\
\text { Laryngoscope: } 1.979\end{array}$ & $\begin{array}{l}25 \text { patients with HIV infection and } 29 \\
\text { healthy controls. The patients received } \\
\text { either placebo or guaifenesin for } 3 \text { weeks. }\end{array}$ & $\begin{array}{l}\text { The STT of the patients was higher than that } \\
\text { of the control group. There was no differ- } \\
\text { ence between the STT of patients receiving } \\
\text { guaifenesin and of those receiving placebo. }\end{array}$ \\
\hline
\end{tabular}


Table 2 (Continued)

\begin{tabular}{|c|c|c|c|}
\hline Category & $\begin{array}{l}\text { Author; publication year; } \\
\text { journal and its impact factor }\end{array}$ & Sample & Obtained results \\
\hline & $\begin{array}{l}\text { Alho et al }{ }^{90} ; 2004 \\
\text { Am J Rhinol: } 1.36\end{array}$ & $\begin{array}{l}9 \text { allergic patients, } 16 \text { with sinusitis, and } 20 \\
\text { healthy subjects were evaluated from the } \\
2^{\text {nd }} \text { to the } 4^{\text {th }} \text { day of flu and after } 3 \text { weeks. }\end{array}$ & $\begin{array}{l}\text { The STT was higher during the flu than in } \\
\text { convalescence. The allergic subjects tended } \\
\text { to present the worst STT. }\end{array}$ \\
\hline & $\begin{array}{l}\text { Philpott et al }{ }^{91} ; 2004 \\
\text { Clin. Otolaryngol } \\
\text { Allied Sci: } 1.869\end{array}$ & $\begin{array}{l}18 \text { pregnant women, followed-up from the } \\
1^{\text {st }} \text { trimester of pregnancy until the } \\
\text { postpartum period. }\end{array}$ & $\begin{array}{l}\text { Accelerated STT was observed in the } 3 \text { rd } \\
\text { gestational trimester compared with } \\
\text { the1st, and also in the postpartum period } \\
\text { compared with the } 3^{\text {rd }} \text { trimester. }\end{array}$ \\
\hline \multirow[t]{2}{*}{$\begin{array}{l}\text { Effects of } \\
\text { environmental } \\
\text { pollution }\end{array}$} & $\begin{array}{l}\text { Priscilla et al }{ }^{36} ; 2011 \\
\text { Lung India }\end{array}$ & $\begin{array}{l}30 \text { adult women who used biomass fuel and } \\
30 \text { adult women who used clean fuel } \\
\text { (control). }\end{array}$ & $\begin{array}{l}\text { STT was higher in women who used biomass } \\
\text { fuel than in the control group. }\end{array}$ \\
\hline & $\begin{array}{l}\text { Ferreira Ceccato et } \text { al }^{92} ; 2011 \\
\text { Respir Med: } 2.585\end{array}$ & $\begin{array}{l}45 \text { young sugarcane cutters, of whom } \\
33 \text { were nonsmokers and } 12 \text { were light } \\
\text { smokers. }\end{array}$ & $\begin{array}{l}\text { The STT was similar between smokers and } \\
\text { nonsmokers and decreased at the end of } \\
\text { the first day of harvest in both groups. }\end{array}$ \\
\hline \multirow[t]{6}{*}{$\begin{array}{l}\text { Effects of drug } \\
\text { interventions }\end{array}$} & $\begin{array}{l}\text { Oysu et } \text { al }^{94} ; 2014 \\
\text { Auris Nasus Larynx: } 0.948\end{array}$ & $\begin{array}{l}42 \text { geriatric patients with nasal symptoms } \\
\text { received either } 2 \text { weeks of isotonic sodium } \\
\text { chloride solution (ISCS) followed by } 2 \text { weeks } \\
\text { of } \mathrm{N} \text {. sativa oil (NG oil), or the same treat- } \\
\text { ment in the inverse order }\end{array}$ & $\begin{array}{l}\text { There was no change in mucociliary clear- } \\
\text { ance during any of the treatment periods. }\end{array}$ \\
\hline & $\begin{array}{l}\text { Gelardi et } \text { al }^{95} ; 2013 \\
\text { Eur Ann Allergy Clin Immunol }\end{array}$ & $\begin{array}{l}36 \text { patients with nasal polyposis received } \\
\text { intranasal sodium hyaluronate } 9 \mathrm{mg} \text { twice } \\
\text { daily or saline solution for } 30 \text { days after } \\
\text { endoscopic sinus surgery }\end{array}$ & $\begin{array}{l}\text { Patients receiving sodium hyaluronate had } \\
\text { faster STTs at } 1 \text { month compared with } \\
\text { controls. }\end{array}$ \\
\hline & $\begin{array}{l}\text { Riechelmann et al }{ }^{96} ; 2003 \\
\text { J Occup Environ Med: } 1.845\end{array}$ & $\begin{array}{l}32 \text { healthy volunteers exposed to } 0 \text { (control), } \\
500,1,000 \text {, and } 5,000 \mu \mathrm{g} / \mathrm{m} 3 \text { of calcium } \\
\text { carbonate powder for } 3 \text { hours. }\end{array}$ & $\begin{array}{l}\text { There was a dose-dependent acceleration in } \\
\text { the STT after exposure to dust concentrations } \\
\text { and a slowing in the control situation. }\end{array}$ \\
\hline & $\begin{array}{l}\text { Bencova et } \text { al }^{97} ; 2012 \\
\text { J Phisiol Pharmacol: } 2.476\end{array}$ & $\begin{array}{l}43 \text { healthy young men made use of inhaled } \\
\text { hypertonic saline solution. }\end{array}$ & $\begin{array}{l}\text { The STT decreased } 30 \text { minutes after inha- } \\
\text { lation of the solution. } \\
\text { There was no correlation between STT and } \\
\text { nasal nitric oxide. }\end{array}$ \\
\hline & $\begin{array}{l}\text { Bilgi et } \text { al }^{31} ; 2011 \\
\text { Eur J Anaesthesiol: } 2.792\end{array}$ & $\begin{array}{l}50 \text { adult patients were divided into two } \\
\text { groups; one received low flow inhalational } \\
\text { anesthesia, and the other, high flow. }\end{array}$ & $\begin{array}{l}\text { The STT in the immediate postoperative } \\
\text { period in both groups was higher than } \\
\text { before the intervention. } \\
\text { The increase in STT of the high flow group } \\
\text { was higher than in the low flow group. }\end{array}$ \\
\hline & $\begin{array}{l}\text { Isaacs et al }^{42} ; 2011 \\
\text { Am J Rhinol Allergy: } 2.302\end{array}$ & $\begin{array}{l}27 \text { healthy adults who received nasal irri- } \\
\text { gation with } 50 \mathrm{ml} \text { of } 1 \% \text { baby shampoo. }\end{array}$ & $\begin{array}{l}\text { The STT was higher } 15 \text { minutes after the } \\
\text { administration of the solution when com- } \\
\text { pared with preadministration. }\end{array}$ \\
\hline \multirow[t]{7}{*}{$\begin{array}{l}\text { Effects of drug } \\
\text { interventions }\end{array}$} & $\begin{array}{l}\text { Cingi et al }{ }^{98} ; 2010 \\
\text { Ther Adv Respir Dis. }\end{array}$ & $\begin{array}{l}100 \text { adult patients with allergic rhinitis, who } \\
\text { used sea water and saline solution spray. }\end{array}$ & $\begin{array}{l}\text { The STT decreased by } 12 \% \text { with the use of } \\
\text { sea water and by } 4 \% \text { with saline solution. }\end{array}$ \\
\hline & $\begin{array}{l}\text { Gorpelioglu et } \text { al }^{40} ; 2010 \\
\text { Int J Dermatol: } 1.342\end{array}$ & $\begin{array}{l}40 \text { young patients with acne vulgaris } \\
\text { received oral isotretinoin for at least } 3 \\
\text { months. }\end{array}$ & $\begin{array}{l}\text { After } 3 \text { months of treatment, the STT of the } \\
\text { patients increased. The STT correlated with } \\
\text { the dosage of the medication. }\end{array}$ \\
\hline & $\begin{array}{l}\text { Fooanant et al }{ }^{99} ; 2008 \\
\text { J Med Assoc Thai. }\end{array}$ & $\begin{array}{l}110 \text { patients with rhinosinusitis undergoing } \\
\text { endoscopic sinus surgery, half of which } \\
\text { received dexpanthenol in sea water spray, } \\
\text { and the other half, saline solution spray. }\end{array}$ & $\begin{array}{l}\text { The STT improved in both groups after } \\
12 \text { weeks of surgery, but there was a greater } \\
\text { magnitude in the group using } \\
\text { dexpanthenol. }\end{array}$ \\
\hline & $\begin{array}{l}\text { Kesimci et } \text { al }^{32} ; 2008 \\
\text { Minerva anestesiol: } 2.818\end{array}$ & $\begin{array}{l}60 \text { patients undergoing neck or ear surgery, } \\
\text { of which } 20 \text { received the anesthetic sevo- } \\
\text { flurane, } 20 \text { isoflurane, and } 20 \text { desflurane. }\end{array}$ & $\begin{array}{l}\text { There was no difference in STTs before and } \\
\text { after the use of each type of anesthesia, or } \\
\text { among the three anesthetics. }\end{array}$ \\
\hline & $\begin{array}{l}\text { Unsal et al }{ }^{100} ; 2008 \\
\text { Am J Otolaryngol: } 1.228\end{array}$ & $\begin{array}{l}54 \text { patients with persistent allergic rhinitis } \\
\text { who underwent chemosurgery with } \\
\text { trichloroacetic acid. }\end{array}$ & $\begin{array}{l}\text { The STT decreased } 1 \text { month and } 1 \text { year } \\
\text { after surgery, when compared with } \\
\text { presurgery. }\end{array}$ \\
\hline & $\begin{array}{l}\text { Zhang et } a^{38} ; 2008 \\
\text { An Otol, Rhinol Laryngol: } 1.05\end{array}$ & $\begin{array}{l}29 \text { healthy subjects received application of } \\
\text { oxymetazoline spray. }\end{array}$ & $\begin{array}{l}\text { The STT of the evaluated subjects increased } \\
\text { after } 30 \text { minutes of the application of } 2 \\
\text { sprays of oxymetazoline. }\end{array}$ \\
\hline & $\begin{array}{l}\text { Kim et al }{ }^{101} ; 2006 \\
\text { Ann Otol Rhinol Laryngol: } 1.05\end{array}$ & $\begin{array}{l}20 \text { patients with chronic sinusitis underwent } \\
\text { endoscopic sinus surgery, and an antibiotic } \\
\text { was administered in one nostril, and in the } \\
\text { other, saline solution. }\end{array}$ & $\begin{array}{l}\text { The STT decreased in all evaluations (1, 3, and } \\
6 \text { months) compared with the time immedi- } \\
\text { ately after surgery, with no difference } \\
\text { between the nostrils. }\end{array}$ \\
\hline
\end{tabular}


Table 2 (Continued)

\begin{tabular}{|c|c|c|c|}
\hline Category & $\begin{array}{l}\text { Author; publication year; } \\
\text { journal and its impact factor }\end{array}$ & Sample & Obtained results \\
\hline \multirow[t]{3}{*}{$\begin{array}{l}\text { Effects of drug } \\
\text { interventions }\end{array}$} & $\begin{array}{l}\text { Saieed et al }{ }^{102} ; 2006 \\
\text { J Clin Pharmacol: } 2.841\end{array}$ & $\begin{array}{l}24 \text { subjects received a single dose of mon- } \\
\text { telukast }(5 \mathrm{mg}) \text {, and } 24 \text { subjects received } \\
\text { placebo. }\end{array}$ & $\begin{array}{l}\text { There was a decrease in STT after the } \\
\text { administration of montelukast compared } \\
\text { with placebo. }\end{array}$ \\
\hline & $\begin{array}{l}\text { Cmejrek et al }^{47} ; 2005 \\
\text { Otolaryngol } \\
\text { Head Neck Surg: } 1.625\end{array}$ & $\begin{array}{l}42 \text { allergic patients treated with immu- } \\
\text { notherapy for } 1 \text { year. Of them, } 23 \text { repeated } \\
\text { the assessment at the end of the treatment. }\end{array}$ & $\begin{array}{l}\text { The STT of the allergic patients was higher } \\
\text { than that of controls described in the lit- } \\
\text { erature. After } 1 \text { year of immunotherapy, } \\
\text { there was improvement in the STT in the } \\
\text { evaluated patients. }\end{array}$ \\
\hline & $\begin{array}{l}\text { Riechelmann et } \mathrm{al}^{103} ; 2004 \\
\text { Am J Rhinol: } 1.36\end{array}$ & $\begin{array}{l}16 \text { healthy individuals subjected to the use } \\
\text { of benzalkonium chloride for } 8 \text { days. }\end{array}$ & $\begin{array}{l}\text { There was no change in the STT of the } \\
\text { evaluated individuals. }\end{array}$ \\
\hline \multirow[t]{3}{*}{$\begin{array}{l}\text { Effects of } \\
\text { surgical } \\
\text { interventions }\end{array}$} & $\begin{array}{l}\text { Yazici et al }{ }^{104} ; 2014 \\
\text { Int J Pediatr } \\
\text { Otorhinolaryngol: } 1.350\end{array}$ & $\begin{array}{l}33 \text { children with adenoid hypertrophy }(\mathrm{AH}) \\
\text { and } 31 \text { with } \mathrm{AH} \text { and otitis media with effu- } \\
\text { sion (AHOME) undergoing surgical } \\
\text { procedure }\end{array}$ & $\begin{array}{l}\text { The STT improved in all patients after sur- } \\
\text { gery. Patients with AHOME had slower pre- } \\
\text { and postoperative STTs. } \\
\text { Exposure to cigarette smoke and adenoid } \\
\text { size had a negative correlation with STT. }\end{array}$ \\
\hline & $\begin{array}{l}\text { Ozkul et al }^{105} ; 2014 \\
\text { J Craniofac Surg: } 1.252\end{array}$ & $\begin{array}{l}23 \text { patients with symptomatic nasoseptal } \\
\text { perforations, treated using the mucosal } \\
\text { regeneration technique. }\end{array}$ & $\begin{array}{l}\text { STT improved at } 3 \text { and } 6 \text { postoperative } \\
\text { months in comparison with the preopera- } \\
\text { tive evaluation }\end{array}$ \\
\hline & $\begin{array}{l}\text { Parida et } a^{106} ; 2013 \\
\text { Indian J Otolaryngol } \\
\text { Head Neck Surg: } 0.054\end{array}$ & $\begin{array}{l}45 \text { patients with symptomatic inferior tur- } \\
\text { binate hypertrophy undergoing diode laser } \\
\text { turbinate reduction }\end{array}$ & $\begin{array}{l}\text { There was prolongation of STT after the } \\
\text { intervention. However, it returned to pre- } \\
\text { operative values after } 6 \text { months. }\end{array}$ \\
\hline \multirow[t]{5}{*}{$\begin{array}{l}\text { Effects of } \\
\text { surgical } \\
\text { interventions }\end{array}$} & $\begin{array}{l}\text { Alobid et al }{ }^{35} ; 2013 \\
\text { Neurosurgery: } 2.532\end{array}$ & $\begin{array}{l}36 \text { patients with pituitary adenoma who } \\
\text { underwent the transnasal trans-sphenoidal } \\
\text { endoscopic approach, and } 14 \text { patients with } \\
\text { other benign tumors undergoing the } \\
\text { expanded endonasal approach. }\end{array}$ & $\begin{array}{l}\text { Both groups showed a higher STT after } \\
\text { surgery compared with baseline. In addi- } \\
\text { tion, patients submitted to the expanded } \\
\text { endonasal approach showed a slower STT } \\
\text { than the other group. }\end{array}$ \\
\hline & $\begin{array}{l}\text { Arnaoutakis et } \mathrm{al}^{24} ; 2011 \\
\text { Int J Pediatr } \\
\text { Otorhinolaryngol: } 1.350\end{array}$ & $\begin{array}{l}10 \text { children with adenoid hypertrophy, } \\
\text { chronic adenoiditis, and/or chronic rhinosi- } \\
\text { nusitis undergoing adenoidectomy. }\end{array}$ & $\begin{array}{l}\text { After } 1 \text { month of surgery, STT decreased } \\
\text { compared with at the preoperative time. }\end{array}$ \\
\hline & $\begin{array}{l}\text { Miwa et al }{ }^{107} ; 2011 \\
\text { Ear Nose Throat J: } 0.66\end{array}$ & $\begin{array}{l}25 \text { patients with chronic sinusitis, } 10 \text { of } \\
\text { whom underwent maxillary sinus coun- } \\
\text { teropening via extranasal approaches; } 8 \\
\text { underwent enlargement of the maxillary } \\
\text { sinus natural by intranasal endoscopic sur- } \\
\text { gery; } 4 \text { received an indwelling maxillary } \\
\text { sinus tube, and } 3 \text { received a Yamik } \\
\text { catheter. }\end{array}$ & $\begin{array}{l}\text { STT was similar between groups prior to the } \\
\text { intervention. The STT decreased in all } \\
\text { patients who underwent deobstruction and } \\
\text { enlargement. In the group receiving the } \\
\text { indwelling tube, the STT increased, and } \\
\text { there was a decrease in STT in the catheter } \\
\text { group. }\end{array}$ \\
\hline & $\begin{array}{l}\text { Yigit et al }{ }^{108} ; 2011 \\
\text { Ear Nose Throat J: } 0.66\end{array}$ & $\begin{array}{l}50 \text { adult patients undergoing endoscopic } \\
\text { dacryocystorhinostomy. }\end{array}$ & $\begin{array}{l}\text { Prior to surgery, the STT of both nostrils } \\
\text { were similar. One and } 3 \text { months after sur- } \\
\text { gery, the operated nostril showed a higher } \\
\text { STT when compared with the contralateral } \\
\text { nostril. }\end{array}$ \\
\hline & $\begin{array}{l}\text { Okuyuku et al }^{44} ; 2009 \\
\text { Otolaryngol } \\
\text { Head Neck Surg: } 1.625\end{array}$ & $\begin{array}{l}22 \text { patients who underwent unilateral } \\
\text { endoscopic dacryocystorhinostomy and } 22 \\
\text { who underwent an external approach. }\end{array}$ & $\begin{array}{l}\text { The procedures resulted in STT increase in } \\
\text { the nostril subjected to intervention com- } \\
\text { pared with the contralateral, and there was } \\
\text { no difference between the protocols. }\end{array}$ \\
\hline \multirow[t]{4}{*}{$\begin{array}{l}\text { Effects of } \\
\text { surgical } \\
\text { interventions }\end{array}$} & $\begin{array}{l}\text { Chen et } \text { al }^{109} ; 2008 \\
\text { Laryngoscope: } 1.979\end{array}$ & $\begin{array}{l}160 \text { patients with allergic rhinitis, of whom } \\
80 \text { underwent submucosal resection of the } \\
\text { inferior turbinate, and } 80 \text { who underwent } \\
\text { assisted inferior turbinoplasty. The control } \\
\text { group comprised } 10 \text { individuals without } \\
\text { respiratory complaints. }\end{array}$ & $\begin{array}{l}\text { Prior to the interventions, the rhinitis } \\
\text { groups had worse STTs than the control } \\
\text { group. One year after the surgery, there was } \\
\text { a decrease in STT, which was maintained for } \\
\text { up to } 3 \text { years in both groups. }\end{array}$ \\
\hline & $\begin{array}{l}\text { Hu et } \text { al }^{110} ; 2008 \\
\text { J Otolaryngol } \\
\text { Head Neck Surg: } 1.625\end{array}$ & $\begin{array}{l}21 \text { patients with nasopharyngeal carcinoma } \\
\text { undergoing endoscopic surgery and } 5 \text { con- } \\
\text { trol subjects. }\end{array}$ & $\begin{array}{l}\text { Control subjects showed lower STTs than } \\
\text { the pre- and postoperative values in the } \\
\text { case group. However, } 1 \text { year after the sur- } \\
\text { gery, there was improvement in the STTs of } \\
\text { the patients. }\end{array}$ \\
\hline & $\begin{array}{l}\text { Sakthikumar et al }{ }^{111} ; 2008 \\
\text { Indian J Otolarygol } \\
\text { Head Neck Surg: } 0.054\end{array}$ & $\begin{array}{l}20 \text { patients with chronic sinusitis under- } \\
\text { went functional endoscopic sinus surgery. }\end{array}$ & $\begin{array}{l}\text { There was a decrease in STT } 6 \text { weeks after } \\
\text { the surgery, when compared with the pre- } \\
\text { surgery evaluation. }\end{array}$ \\
\hline & $\begin{array}{l}\text { Chen et al }{ }^{112} ; 2007 \\
\text { Int J Pediatr } \\
\text { Otorhinolaryngol: } 1.350\end{array}$ & $\begin{array}{l}120 \text { children with chronic nasal obstruction. } \\
60 \text { underwent submucosal resection (SR), } \\
\text { and } 60 \text { underwent microdebrider-assisted }\end{array}$ & $\begin{array}{l}\text { Before surgery, the STT of the children with } \\
\text { nasal obstruction was higher than that of } \\
\text { the control group. }\end{array}$ \\
\hline
\end{tabular}


Table 2 (Continued)

\begin{tabular}{|c|c|c|c|}
\hline Category & $\begin{array}{l}\text { Author; publication year; } \\
\text { journal and its impact factor }\end{array}$ & Sample & Obtained results \\
\hline & & $\begin{array}{l}\text { inferior turbinoplasty (MAIT), and, for con- } \\
\text { trol, } 10 \text { children without respiratory } \\
\text { discomfort. }\end{array}$ & $\begin{array}{l}\text { One week after the SR, there was an } \\
\text { increase in STT, followed by a decrease } \\
1 \text { month after the surgery. The MAIT group } \\
\text { presented no changes in STT at any of the } \\
\text { evaluated moments. }\end{array}$ \\
\hline & $\begin{array}{l}\text { Clayman et al }{ }^{113} ; 2006 \\
\text { Otolaryngol } \\
\text { Head Neck Surg: } 1.625\end{array}$ & $\begin{array}{l}5 \text { patients with allergic rhinitis undergoing } \\
\text { inferior turbinectomy. }\end{array}$ & $\begin{array}{l}\text { The STT mean, performed after } 22.6 \text { years } \\
\text { of intervention, was } 11.8 \text { minutes. }\end{array}$ \\
\hline \multirow[t]{3}{*}{$\begin{array}{l}\text { Effects of } \\
\text { surgical } \\
\text { interventions }\end{array}$} & $\begin{array}{l}\text { Deniz et } \mathrm{al}^{41} ; 2006 \\
\text { Eur Arch } \\
\text { Otorhinolaryngol: } 1.458\end{array}$ & $\begin{array}{l}39 \text { patients underwent total laryngectomy, } \\
\text { divided by time since the operation (more } \\
\text { or less than } 2 \text { years) and also with associated } \\
\text { conditions such as diabetes mellitus and } \\
\text { smoking. The control group consisted of } 36 \\
\text { healthy individuals. }\end{array}$ & $\begin{array}{l}\text { The STT of individuals who had }<2 \text { years since } \\
\text { the surgery was lower than that of the control } \\
\text { group. However, patients with }>2 \text { years since } \\
\text { the laryngectomy had higher STTs. } \\
\text { Diabetic subjects, as well as smokers, pre- } \\
\text { sented higher STTs than healthy subjects, both } \\
\text { in the surgery and control groups. }\end{array}$ \\
\hline & $\begin{array}{l}\text { Huang et al }{ }^{114} ; 2006 \\
\text { Int J Pediatr } \\
\text { Otorhinolaryngol: } 1.350\end{array}$ & $\begin{array}{l}25 \text { children with edematous and polypoid } \\
\text { sinusitis undergoing endoscopic surgery, } \\
\text { and } 5 \text { controls without sinusitis, undergoing } \\
\text { adenoidectomy. }\end{array}$ & $\begin{array}{l}\text { There was improvement in the STT after } \\
\text { surgery in children with both types of sinusitis, } \\
\text { and the group of edematous sinusitis became } \\
\text { similar to the control group. }\end{array}$ \\
\hline & $\begin{array}{l}\text { Unal et al }{ }^{46} ; 2004 \\
\text { Clin Otolaryngol } \\
\text { Allied Sci: } 1.869\end{array}$ & $\begin{array}{l}17 \text { patients undergoing } \\
\text { dacryocystorhinostomy. }\end{array}$ & $\begin{array}{l}\text { Three months after the surgery, the oper- } \\
\text { ated nostril showed a worse STT compared } \\
\text { with the side that had no obstruction. }\end{array}$ \\
\hline \multirow[t]{2}{*}{$\begin{array}{l}\text { Other } \\
\text { interventions }\end{array}$} & $\begin{array}{l}\text { Bhardwaj et al }{ }^{115} ; 2013 \\
\text { AYU }\end{array}$ & $\begin{array}{l}40 \text { patients with rhinosinusitis practiced } \\
\text { alternate nostril breathing exercise for } 40 \\
\text { days, } 30 \text { minutes daily, for } 2 \text { months }\end{array}$ & $\begin{array}{l}\text { There was a reduction in the STT at the end } \\
\text { of the intervention period. }\end{array}$ \\
\hline & $\begin{array}{l}\text { Develioglu et } \text { al }^{51} ; 2013 \\
\text { Eur Arch } \\
\text { Otorhinolaryngol: } 1.458\end{array}$ & $\begin{array}{l}40 \text { adults underwent Ramadan (fasting on } \\
\text { average } 15 \text { hours per day for } 29 \text { days), and } \\
26 \text { adults underwent Nineveh ( } 60 \text { uninter- } \\
\text { rupted hours of fasting). }\end{array}$ & $\begin{array}{l}\text { Individuals who underwent Nineveh had } \\
\text { slower STTs at the end of fasting than after } 4 \\
\text { weeks of normal diet. There was no differ- } \\
\text { ence in the STT of the Ramadan group, or } \\
\text { between groups. }\end{array}$ \\
\hline \multirow[t]{6}{*}{$\begin{array}{l}\text { Other } \\
\text { interventions }\end{array}$} & $\begin{array}{l}\text { Oozawa et al }{ }^{12} ; 2012 \\
\text { Auris Nasus Larynx: } 0.948\end{array}$ & $\begin{array}{l}14 \text { healthy men were exposed to low rela- } \\
\text { tive humidity }(\mathrm{RH}) \text { for } 4 \text { hours with prehy- } \\
\text { dration with water, carbohydrate- } \\
\text { electrolyte beverage (CE), and without } \\
\text { prehydration (control). }\end{array}$ & $\begin{array}{l}\text { The STT increased less in the CE group after } 2 \\
\text { hours compared with the low RH exposure } \\
\text { group. Control and hydrated with water groups } \\
\text { were not different. After } 4 \text { hours of low RH, the } \\
3 \text { groups presented similar increases in STT. }\end{array}$ \\
\hline & $\begin{array}{l}\text { Parida et al }{ }^{116} ; 2011 \\
\text { Indian J Med Sci: } 1.67\end{array}$ & $\begin{array}{l}50 \text { patients with allergic rhinitis and per- } \\
\text { manent nasal obstruction undergoing tis- } \\
\text { sue volume reduction by radiofrequency. }\end{array}$ & $\begin{array}{l}\text { The STT did not change significantly } \\
\text { between preintervention and } 1,3 \text {, and } 6 \\
\text { months postintervention, except } 1 \text { week } \\
\text { after the intervention. }\end{array}$ \\
\hline & $\begin{array}{l}\text { Ramos et al }{ }^{34} ; 2011 \\
\text { Respirology: } 2.781\end{array}$ & $\begin{array}{l}33 \text { smokers enrolled in a smoking cessation } \\
\text { program, and } 33 \text { nonsmokers (control). }\end{array}$ & $\begin{array}{l}\text { Before quitting smoking, smokers showed } \\
\text { higher STTs than controls. After } 15 \text { days of } \\
\text { smoking abstinence, the STT decreased to } \\
\text { normal levels and remained at these levels } \\
\text { after } 30,60,90,120 \text {, and } 180 \text { days of } \\
\text { abstinence. }\end{array}$ \\
\hline & $\begin{array}{l}\text { Gupta et al }{ }^{117} ; 2006 \\
\text { Indian J Otolaryngol } \\
\text { Head Neck Surg: } 0.054\end{array}$ & $\begin{array}{l}50 \text { patients with head and neck cancer } \\
\text { treated with radiotherapy, and } 20 \text { healthy } \\
\text { subjects who received no irradiation. }\end{array}$ & $\begin{array}{l}\text { Before starting the radiation therapy, the } \\
\text { STTs of the patients were similar to those of } \\
\text { the control subjects. However, } 6 \text { months } \\
\text { after the end of the treatment, the STT of } \\
\text { the case group was impaired. }\end{array}$ \\
\hline & $\begin{array}{l}\text { de Oliveira et al }{ }^{33} ; 2006 \\
\text { Respir Med: } 2.585\end{array}$ & $\begin{array}{l}11 \text { healthy subjects underwent } 20 \text { minutes } \\
\text { of CPAP, and } 5 \text { controls, evaluated after } 20 \\
\text { minutes of rest. }\end{array}$ & $\begin{array}{l}\text { The STT decreased immediately after the } \\
\text { use of CPAP and did not change in the } \\
\text { control group. }\end{array}$ \\
\hline & $\begin{array}{l}\text { Kamel et al }{ }^{118} ; 2004 \\
\text { Acta Otolaryngol: } 1.106\end{array}$ & $\begin{array}{l}32 \text { patients with nasopharyngeal carcinoma } \\
\text { undergoing radiotherapy. }\end{array}$ & $\begin{array}{l}\text { There was an increase in STT after } \\
\text { radiotherapy. }\end{array}$ \\
\hline
\end{tabular}

Abbreviations: $\mu \mathrm{g} / \mathrm{m}^{3}$, micrograms per cubic meter; CPAP, continuous positive airway pressure; ex CO, exhaled carbon monoxide; HIV, human immunodeficiency virus; ICU, intensive care unit; min, minutes; STT, saccharin transit time. 
The amount of introduced saccharin is standardized as 2.5 micrograms, which corresponds to $\sim 5$ particles of the substance.

Execution of the STT test: Subjects are in a sitting position, with the head supported in a slight extension $\left(\sim 10^{\circ}\right.$ neck extension) (-Fig. 1B).

The placement of saccharin is performed under visual control, $2 \mathrm{~cm}$ into the inferior turbinates of the right nostril of the subjects. The right nostril is chosen as a way of standardizing and facilitating the reproduction of the method.

Subjects are asked to maintain their natural breathing and swallowing and not to get up, talk, cough, sneeze, or manipulate their nose. If this happens, the test is cancelled and rescheduled for another day. These guidelines are to prevent the change in airflow or mechanical touches from modifying the movement of the particles and interfering with the test results.

The expected flavor and nature of the substance should not be disclosed to prevent false positives.

\section{Limitations of the Method}

Despite subjects being instructed on how to breathe and swallow, these aspects are not objectively controlled by the evaluators and can vary among volunteers.

The test does not present visible results for evaluators, who take the report of the subjects as true. One way to avoid a false positive is not revealing the real flavor of the substance to be perceived by the subject, so the result is more reliable.

Even though saccharin presents a strong taste, its perception is subjective and may vary among subjects, and it is possible that some of them present altered taste, which would interfere in the results, not due to MCC conditions, but to individual taste perception.

The placement of saccharin, although not invasive, requires great attention and some manual skill training from the evaluator, since anatomical differences may hinder the insertion of the particle and even interfere with the exact location of deposition.

Cleaning the nostrils before the evaluation may be helpful to avoid possible additional mechanical barriers to the passage of the particle. However, the act of blowing the nose of the subject can interfere with the MCC due to the change in airflow.

\section{Discussion}

The STT test is an effective and widely used method in scientific research related to nasal MCC, which is essential in maintaining the health of the respiratory system. However, despite its simple implementation, some care is necessary to guarantee reliable results. In addition, a standardization of the application protocol is recommended so that future comparisons between different studies employing STT become possible in a reliable way.

The factors that can interfere with the results obtained by the STT test are worth highlighting: age, temperature, circadian cycle, presence of infections, use of drugs, of caffeinebased or of alcoholic substances, presence and intensity of smoking as well time of abstinence, physical exercise performance, and level of physical activity in daily life.

\section{Final Comments}

It is concluded that STT test is a widely used method for evaluation of nasal MCC, and, therefore, a standardization related to prior and concurrent test guidelines to professionals as well as to their execution is essential to improve the accuracy of the test, and to allow comparisons among different studies that employ it.

\section{References}

1 Scheuch G, Kohlhäufl M, Möller W, et al. Particle clearance from the airways of subjects with bronchial hyperresponsiveness and with chronic obstructive pulmonary disease. Exp Lung Res 2008; 34(09):531-549

2 Nakagawa NK, Franchini ML, Driusso P, de Oliveira LR, Saldiva PH, Lorenzi-Filho G. Mucociliary clearance is impaired in acutely ill patients. Chest 2005;128(04):2772-2777

3 Moriarty BG, Robson AM, Smallman LA, Drake-Lee AB. Nasal mucociliary function: comparison of saccharin clearance with ciliary beat frequency. Rhinology 1991;29(03):173-179

4 Hasani A, Toms N, Agnew JE, Lloyd J, Dilworth JP. Mucociliary clearance in COPD can be increased by both a D2/beta2 and a standard beta2 agonists. Respir Med 2005;99(02):145-151

5 Ferri RG, Zonato A, Guilherme A, et al. Análise do clearance mucociliar nasal e dos efeitos adversos do uso de CPAP. Rev Bras Otorrinolaringol 2004;70(02):150-155

6 Elliott MK, Sisson JH, Wyatt TA. Effects of cigarette smoke and alcohol on ciliated tracheal epithelium and inflammatory cell recruitment. Am J Respir Cell Mol Biol 2007;36(04):452-459

7 Smith DJ, Gaffney EA, Blake JR. Modelling mucociliary clearance. Respir Physiol Neurobiol 2008;163(1-3):178-188

8 Bhowmik A, Chahal K, Austin G, Chakravorty I. Improving mucociliary clearance in chronic obstructive pulmonary disease. Respir Med 2009;103(04):496-502

9 Mall MA. Role of cilia, mucus, and airway surface liquid in mucociliary dysfunction: lessons from mouse models. J Aerosol Med Pulm Drug Deliv 2008;21(01):13-24

10 Bush A, Cole P, Hariri M, et al. Primary ciliary dyskinesia: diagnosis and standards of care. Eur Respir J 1998;12(04):982-988

11 Ho JC, Chan KN, Hu WH, et al. The effect of aging on nasal mucociliary clearance, beat frequency, and ultrastructure of respiratory cilia. Am J Respir Crit Care Med 2001;163(04):983-988

12 Oozawa H, Kimura H, Noda T, Hamada K, Morimoto T, Majima Y. Effect of prehydration on nasal mucociliary clearance in low relative humidity. Auris Nasus Larynx 2012;39(01):48-52

13 Chilvers MA, Rutman A, O'Callaghan C. Ciliary beat pattern is associated with specific ultrastructural defects in primary ciliary dyskinesia. J Allergy Clin Immunol 2003;112(03):518-524

14 Macchione M, Guimarães ET, Saldiva PH, Lorenzi-Filho G. Methods for studying respiratory mucus and mucus clearance. Braz J Med Biol Res 1995;28(11-12):1347-1355

15 Trindade SH, de Mello JFJ Jr, Mion OdeG, et al. Methods for studying mucociliary transport. Rev Bras Otorrinolaringol (Engl Ed) $2007 ; 73(05): 704-712$

16 Lima Afonso J, Tambascio J, Dutra de Souza HC, Jardim JR, Baddini Martinez JA, Gastaldi AC. [Transport of mucoid mucus in healthy individuals and patients with chronic obstructive pulmonary disease and bronchiectasis]. Rev Port Pneumol 2013;19(05):211-216

17 Bennett WD, Laube BL, Corcoran T, et al. Multisite comparison of mucociliary and cough clearance measures using standardized methods. J Aerosol Med Pulm Drug Deliv 2013;26(03):157-164

18 Stanley P, MacWilliam L, Greenstone M, Mackay I, Cole P. Efficacy of a saccharin test for screening to detect abnormal mucociliary clearance. Br J Dis Chest 1984;78(01):62-65 
19 Puchelle E, Aug F, Pham QT, Bertrand A. Comparison of three methods for measuring nasal mucociliary clearance in man. Acta Otolaryngol 1981;91(3-4):297-303

20 Corbo GM, Foresi A, Bonfitto P, Mugnano A, Agabiti N, Cole PJ. Measurement of nasal mucociliary clearance. Arch Dis Child 1989;64(04):546-550

21 Plaza Valía P, Carrión Valero F, Marín Pardo J, Bautista Rentero D, González Monte C. [Saccharin test for the study of mucociliary clearance: reference values for a Spanish population]. Arch Bronconeumol 2008;44(10):540-545

22 Proença de Oliveira-Maul J, Barbosa de Carvalho H, Goto DM, et al. Aging, diabetes, and hypertension are associated with decreased nasal mucociliary clearance. Chest 2013;143(04):1091-1097

23 Proença M, Fagundes Xavier R, Ramos D, Cavalheri V, Pitta F, Cipulo Ramos EM. [Immediate and short term effects of smoking on nasal mucociliary clearance in smokers]. Rev Port Pneumol 2011;17(04):172-176

24 Arnaoutakis D, Collins WO. Correlation of mucociliary clearance and symptomatology before and after adenoidectomy in children. Int J Pediatr Otorhinolaryngol 2011;75(10):1318-1321

25 Naiboglu B, Deveci I, Kalaycik C, et al. Effect of nasolacrimal duct obstruction on nasal mucociliary transport. J Laryngol Otol 2010;124(02):166-170

26 Andersen I, Camner P, Jensen PL, Philipson K, Proctor DF. A comparison of nasal and tracheobronchial clearance. Arch Environ Health 1974;29(05):290-293

27 Rutland J, Cole PJ. Nasal mucociliary clearance and ciliary beat frequency in cystic fibrosis compared with sinusitis and bronchiectasis. Thorax 1981;36(09):654-658

28 Proença M, Pitta F, Kovelis D, et al. Mucociliary clearance and its relation with the level of physical activity in daily life in healthy smokers and nonsmokers. Rev Port Pneumol 2012;18(05):233-238

29 Stanley PJ, Wilson R, Greenstone MA, MacWilliam L, Cole PJ. Effect of cigarette smoking on nasal mucociliary clearance and ciliary beat frequency. Thorax 1986;41(07):519-523

30 Wilson R, Sykes DA, Currie D, Cole PJ. Beat frequency of cilia from sites of purulent infection. Thorax 1986;41(06):453-458

31 Bilgi M, Goksu S, Mizrak A, et al. Comparison of the effects of lowflow and high-flow inhalational anaesthesia with nitrous oxide and desflurane on mucociliary activity and pulmonary function tests. Eur J Anaesthesiol 2011;28(04):279-283

32 Kesimci E, Bercin S, Kutluhan A, Ural A, Yamanturk B, Kanbak O. Volatile anesthetics and mucociliary clearance. Minerva Anestesiol 2008;74(04):107-111

33 de Oliveira LR, Albertini Yagi CS, Figueiredo AC, Saldiva PH, Lorenzi-Filho G. Short-term effects of nCPAP on nasal mucociliary clearance and mucus transportability in healthy subjects. Respir Med 2006;100(01):183-185

34 Ramos EM, De Toledo AC, Xavier RF, et al. Reversibility of impaired nasal mucociliary clearance in smokers following a smoking cessation programme. Respirology 2011;16(05):849-855

35 Alobid I, Enseñat J, Mariño-Sánchez F, et al. Impairment of olfaction and mucociliary clearance after expanded endonasal approach using vascularized septal flap reconstruction for skull base tumors. Neurosurgery 2013;72(04):540-546

36 Priscilla J, Padmavathi R, Ghosh S, et al. Evaluation of mucociliary clearance among women using biomass and clean fuel in a periurban area of Chennai: A preliminary study. Lung India 2011;28(01):30-33

37 Delehaye E, Dore MP, Bozzo C, Mameli L, Delitala G, Meloni F. Correlation between nasal mucociliary clearance time and gastroesophageal reflux disease: our experience on 50 patients. Auris Nasus Larynx 2009;36(02):157-161

38 Zhang L, Han D, Song X, Wang K, Wang H. Effect of oxymetazoline on healthy human nasal ciliary beat frequency measured with high-speed digital microscopy and mucociliary transport time. Ann Otol Rhinol Laryngol 2008;117(02):127-133
39 Salah B, Dinh Xuan AT, Fouilladieu JL, Lockhart A, Regnard J. Nasal mucociliary transport in healthy subjects is slower when breathing dry air. Eur Respir J 1988;1(09):852-855

40 Gorpelioglu C, Ozol D, Sarifakioglu E. Influence of isotretinoin on nasal mucociliary clearance and lung function in patients with acne vulgaris. Int J Dermatol 2010;49(01):87-90

41 Deniz M, Uslu C, Ogredik EA, Akduman D, Gursan So. Nasal mucociliary clearance in total laryngectomized patients. Eur Arch Otorhinolaryngol 2006;263(12):1099-1104

42 Isaacs S, Fakhri S, Luong A, Whited C, Citardi MJ. The effect of dilute baby shampoo on nasal mucociliary clearance in healthy subjects. Am J Rhinol Allergy 2011;25(01):e27-e29

43 Rosen EJ, Calhoun KH. Alterations of nasal mucociliary clearance in association with HIV infection and the effect of guaifenesin therapy. Laryngoscope 2005;115(01):27-30

44 Okuyucu S, Akoglu E, Oksuz H, Gorur H, Dagli S. The effect of dacryocystorhinostomy on mucociliary function. Otolaryngol Head Neck Surg 2009;140(04):585-588

45 Middleton PG, Geddes DM, Alton EW. Effect of amiloride and saline on nasal mucociliary clearance and potential difference in cystic fibrosis and normal subjects. Thorax 1993;48(08):812-816

46 Unal M, Oz O, Adigüzel U, Vayisoglu Y, Vatansever H, Görür K. Mucociliary clearance after external dacryocystorhinostomy. Clin Otolaryngol Allied Sci 2004;29(03):264-265

47 Cmejrek RC, Gutman MT, Torres AJ, Keen KJ, Houser SM. The effect of injection immunotherapy on mucociliary clearance in allergic patients. Otolaryngol Head Neck Surg 2005;133(01):9-15

48 Boatsman JE, Calhoun KH, Ryan MW. Relationship between rhinosinusitis symptoms and mucociliary clearance time. Otolaryngol Head Neck Surg 2006;134(03):491-493

49 Xavier RF, Ramos D, Ito JT, et al. Effects of cigarette smoking intensity on the mucociliary clearance of active smokers. Respiration 2013;86(06):479-485

50 Altuntaş EE, Kaya A, Uysal IO, Cevit Ö, Içağasioğlu D, Müderris S. Anterior rhinomanometry and determination of nasal mucociliary clearance time with the saccharin test in children with Crimean-Congo hemorrhagic fever. J Craniofac Surg 2013;24 (03):e239-e242

51 Develioglu ON, Sirazi S, Topak M, Purisa S, Kulekci M. Differences in Mucociliary activity of volunteers undergoing Ramadan versus Nineveh fasting. Eur Arch Otorhinolaryngol 2013;270 (05):1655-1659

52 Bercin S, Ural A, Kutluhan A. Effects of topical drops and sprays on mucociliary transport time and nasal air flow. Acta Otolaryngol 2009;129(11):1257-1261

53 Yoruk O, Ates O, Araz O, et al. The effects of silica exposure on upper airways and eyes in denim sandblasters. Rhinology 2008; 46(04):328-333

54 Wolff RK, Dolovich MB, Obminski G, Newhouse MT. Effects of exercise and eucapnic hyperventilation on bronchial clearance in man. J Appl Physiol 1977;43(01):46-50

55 Svartengren M, Falk R, Philipson K. Long-term clearance from small airways decreases with age. Eur Respir J 2005;26(04): 609-615

56 Kamani T, Yilmaz T, Surucu S, Turan E, Brent KA. Scanning electron microscopy of ciliae and saccharine test for ciliary function in septal deviations. Laryngoscope 2006;116(04):586-590

57 Rubin AS, Cavalazzi AC, Viegas CAA, et al. Diretrizes para testes de funçao pulmonar. J Bras Pneumol 2002;28(03):237

58 Koop CE, Luoto J. "The Health Consequences of Smoking: Cancer," overview of a report of the Surgeon General. Public Health Rep 1982;97(04):318-324

59 Wattenberg EV. Noncarcinogenic effects of cigarette smoke on the respiratory tract. Environment Health Sci 2012;8:10

60 Comandini A, Rogliani P, Nunziata A, Cazzola M, Curradi G, Saltini C. Biomarkers of lung damage associated with tobacco smoke in induced sputum. Respir Med 2009;103(11):1592-1613 
61 Cannon JG, Meydani SN, Fielding RA, et al. Acute phase response in exercise. II. Associations between vitamin E, cytokines, and muscle proteolysis. Am J Physiol 1991;260(6 Pt 2):R1235-R1240

62 Nieman DC, Nehlsen-Cannarella SL. The immune response to exercise. Semin Hematol 1994;31(02):166-179

63 Holmqvist N, Secher NH, Sander-Jensen K, Knigge U, Warberg J, Schwartz TW. Sympathoadrenal and parasympathetic responses to exercise. J Sports Sci 1986;4(02):123-128

64 Devalia JL, Sapsford RJ, Rusznak C, Toumbis MJ, Davies RJ. The effects of salmeterol and salbutamol on ciliary beat frequency of cultured human bronchial epithelial cells, in vitro. Pulm Pharmacol 1992;5(04):257-263

65 Sisson JH. Alcohol and airways function in health and disease. Alcohol 2007;41(05):293-307

66 Monda M, Viggiano A, Vicidomini C, et al. Espresso coffee increases parasympathetic activity in young, healthy people. Nutr Neurosci 2009;12(01):43-48

67 Yeragani VK, Krishnan S, Engels HJ, Gretebeck R. Effects of caffeine on linear and nonlinear measures of heart rate variability before and after exercise. Depress Anxiety 2005;21(03):130-134

68 Yeates DB, Aspin N, Levison H, Jones MT, Bryan AC. Mucociliary tracheal transport rates in man. J Appl Physiol 1975;39(03): 487-495

69 Cammer P, Strandberg K, Philipson K. Increased mucociliary transport by cholinergic stimulation. Arch Environ Health 1974;29(04):220-224

70 Foster WM, Bergofsky EH, Bohning DE, Lippmann M, Albert RE. Effect of adrenergic agents and their mode of action on mucociliary clearance in man. J Appl Physiol 1976;41(02):146-152

71 Begrow F, Böckenholt C, Ehmen M, Wittig T, Verspohl EJ. Effect of myrtol standardized and other substances on the respiratory tract: ciliary beat frequency and mucociliary clearance as parameters. Adv Ther 2012;29(04):350-358

72 Boek WM, Graamans K, Natzijl H, van Rijk PP, Huizing EH. Nasal mucociliary transport: new evidence for a key role of ciliary beat frequency. Laryngoscope 2002;112(03):570-573

73 Houtmeyers E, Gosselink R, Gayan-Ramirez G, Decramer M. Effects of drugs on mucus clearance. Eur Respir J 1999;14(02): 452-467

74 Moore RY. Circadian rhythms: basic neurobiology and clinical applications. Annu Rev Med 1997;48:253-266

75 Stephenson R. Do circadian rhythms in respiratory control contribute to sleep-related breathing disorders? Sleep Med Rev 2003;7(06):475-490

76 Mortola JP. Breathing around the clock: an overview of the circadian pattern of respiration. Eur J Appl Physiol 2004;91 (2-3):119-129

77 McFadden ER Jr. Circadian rhythms. Am J Med 1988;85(1B):2-5

78 Sahin-Yilmaz A, Naclerio RM. Anatomy and physiology of the upper airway. Proc Am Thorac Soc 2011;8(01):31-39

79 Cruz AA, Togias A. Upper airways reactions to cold air. Curr Allergy Asthma Rep 2008;8(02):111-117

80 Kilgour E, Rankin N, Ryan S, Pack R. Mucociliary function deteriorates in the clinical range of inspired air temperature and humidity. Intensive Care Med 2004;30(07):1491-1494

81 Proctor DF, Andersen I, Lundqvist GR. Human nasal mucosal function at controlled temperatures. Respir Physiol 1977;30 (1-2):109-124

82 Jorissen M, Bessems A. Influence of culture duration and ciliogenesis on the relationship between ciliary beat frequency and temperature in nasal epithelial cells. Eur Arch Otorhinolaryngol 1995;252(08):451-454

83 Smith CM, Hirst RA, Bankart MJ, et al. Cooling of cilia allows functional analysis of the beat pattern for diagnostic testing. Chest 2011;140(01):186-190

84 Rodway GW, Windsor JS. Airway mucociliary function at high altitude. Wilderness Environ Med 2006;17(04):271-275
85 Fokkens WJ, Scheeren RA. Upper airway defence mechanisms. Paediatr Respir Rev 2000;1(04):336-341

86 Deniz M, Gultekin E, Ciftci Z, et al. Nasal mucociliary clearance in obstructive sleep apnea syndrome patients. Am J Rhinol Allergy 2014;28(05):178-180

87 Baby MK, Muthu PK, Johnson P, Kannan S. Effect of cigarette smoking on nasal mucociliary clearance: A comparative analysis using saccharin test. Lung India 2014;31(01):39-42

88 Janic T, Niedzielska I. Mucociliary clearance impairment after zygomaticomaxillary-orbital fractures. Oral Surg Oral Med Oral Pathol Oral Radiol 2013;115(06):e6-e12

89 Kirtsreesakul V, Somjareonwattana P, Ruttanaphol S. The correlation between nasal symptom and mucociliary clearance in allergic rhinitis. Laryngoscope 2009;119(08):1458-1462

90 Alho OP. Nasal airflow, mucociliary clearance, and sinus functioning during viral colds: effects of allergic rhinitis and susceptibility to recurrent sinusitis. Am J Rhinol 2004;18(06):349-355

91 Philpott CM, Conboy P, Al-Azzawi F, Murty G. Nasal physiological changes during pregnancy. Clin Otolaryngol Allied Sci 2004;29 (04):343-351

92 Ferreira-Ceccato AD, Ramos EM, de Carvalho LCJ Jr, et al. Short-term effects of air pollution from biomass burning in mucociliary clearance of Brazilian sugarcane cutters. Respir Med 2011;105(11):1766-1768

93 Cinar F, Beder L. Nasal mucociliary clearance in coal mine workers. Otolaryngol Head Neck Surg 2004;130(06):767-769

94 Oysu C, Tosun A, Yilmaz HB, Sahin-Yilmaz A, Korkmaz D, Karaaslan A. Topical Nigella Sativa for nasal symptoms in elderly. Auris Nasus Larynx 2014;41(03):269-272

95 Gelardi M, Guglielmi AV, De Candia N, Maffezzoni E, Berardi P, Quaranta N. Effect of sodium hyaluronate on mucociliary clearance after functional endoscopic sinus surgery. Eur Ann Allergy Clin Immunol 2013;45(03):103-108

96 Riechelmann H, Rettinger G, Weschta M, Keck T, Deutschle T. Effects of low-toxicity particulate matter on human nasal function. J Occup Environ Med 2003;45(01):54-60

97 Bencova A, Vidan J, Rozborilova E, Kocan I. The impact of hypertonic saline inhalation on mucociliary clearance and nasal nitric oxide. J Physiol Pharmacol 2012;63(03):309-313

98 Cingi $\mathrm{C}$, Unlu $\mathrm{HH}$, Songu M, et al. Seawater gel in allergic rhinitis: entrapment effect and mucociliary clearance compared with saline. Ther Adv Respir Dis 2010;4(01):13-18

99 Fooanant S, Chaiyasate S, Roongrotwattanasiri K. Comparison on the efficacy of dexpanthenol in sea water and saline in postoperative endoscopic sinus surgery. J Med Assoc Thai 2008;91 (10):1558-1563

100 Unsal Tuna EE, Ozbek C, Koç C, Ozdem C. Evaluation of nasal symptoms and mucociliary function in patients with allergic rhinitis treated with chemosurgery using trichloroacetic acid. Am J Otolaryngol 2008;29(01):37-41

101 Kim ST, Gang IG, Cha HE, Ha JS, Chung YS. Effect of mitomycin C on the size of antrostomy after endoscopic sinus surgery. Ann Otol Rhinol Laryngol 2006;115(09):673-678

102 Saieed WN, Alpachachi IA, Almashhadani WM. The effect of montelukast on nasal mucociliary clearance. J Clin Pharmacol 2006;46(05):588-590

103 Riechelmann H, Deutschle T, Stuhlmiller A, Gronau S, Bürner H. Nasal toxicity of benzalkonium chloride. Am J Rhinol 2004;18 (05):291-299

104 Yazici H, Soy FK, Kulduk E, et al. Comparison of nasal mucociliary clearance in adenoid hypertrophy with or without otitis media with effusion. Int J Pediatr Otorhinolaryngol 2014;78(07):1143-1146

105 Ozkul HM, Balikci HH, Karakas M, Bayram O, Bayram AA, Kara N. Repair of symptomatic nasoseptal perforations using mucosal regeneration technique with interpositional grafts. J Craniofac Surg 2014;25(01):98-102

106 Parida PK, Surianarayanan G, Alexander A, Saxena SK, Santhosh K. Diode laser turbinate reduction in the treatment of 
symptomatic inferior turbinate hypertrophy. Indian J Otolaryngol Head Neck Surg 2013;65(Suppl 2):350-355

107 Miwa M, Miwa M, Watanabe K. Changes in intramaxillary sinus pressure following antrostomy, draining tubes, and YAMIK procedures in 25 patients treated for chronic paranasal sinusitis. Ear Nose Throat J 2011;90(08):368-381

108 Yigit O, Kirgezen T, Taskin U, Yener M. Endoscopic dacryocystorhinostomy appears to impair nasal mucociliary clearance. Ear Nose Throat J 2011;90(09):E23-E27

109 Chen YL, Tan CT, Huang HM. Long-term efficacy of microdebriderassisted inferior turbinoplasty with lateralization for hypertrophic inferior turbinates in patients with perennial allergic rhinitis. Laryngoscope 2008;118(07):1270-1274

$110 \mathrm{Hu}$ KH, Tan CT, Lin KN, Cheng YJ, Huang HM. Effect of endoscopic sinus surgery on irradiation-induced rhinosinusitis in patients with nasopharyngeal carcinoma. Otolaryngol Head Neck Surg 2008;139(04):575-579

111 Sakthikumar KR, Ravikumar A, Mohanty S, Senthil K, Somu L, Kuruvilla S. Functional study of nasal mucosa in endoscopic sinus surgery and its correlation to electron microscopy of cilia. Indian J Otolaryngol Head Neck Surg 2008;60(01):1-6

112 Chen YL, Liu CM, Huang HM. Comparison of microdebrider-assisted inferior turbinoplasty and submucosal resection for children with hypertrophic inferior turbinates. Int J Pediatr Otorhinolaryngol 2007;71(06):921-927

113 Clayman MA, Clayman LZ. Twenty year follow-up of ciliary mobility after bilateral inferior turbinectomy for allergic rhinitis using saccharin. Otolaryngol Head Neck Surg 2006;134(04):703-704

114 Huang HM, Cheng JJ, Liu CM, Lin KN. Mucosal healing and mucociliary transport change after endoscopic sinus surgery in children with chronic maxillary sinusitis. Int J Pediatr Otorhinolaryngol 2006;70(08):1361-1367

115 Bhardwaj A, Sharma MK, Gupta M. Endoscopic evaluation of therapeutic effects of "Anuloma-Viloma Pranayama" in Pratishyaya w.s.r. to mucociliary clearance mechanism and Bernoulli's principle. Ayu 2013;34(04):361-367

116 Parida PK, Santhosh K, Ganesan S, Surianarayanan G, Saxena SK. The efficacy of radiofrequency volumetric tissue reduction of hypertrophied inferior turbinate in allergic rhinitis. Indian J Med Sci 2011;65(07):269-277

117 Gupta SC, Chandra S, Singh M. Effects of irradiation on nasal mucociliary clearance in head and neck cancer patients. Indian J Otolaryngol Head Neck Surg 2006;58(01):46-50

118 Kamel R, Al-Badawy S, Khairy A, Kandil T, Sabry A. Nasal and paranasal sinus changes after radiotherapy for nasopharyngeal carcinoma. Acta Otolaryngol 2004;124(04):532-535 